\title{
European Material Culture in Indigenous Sites in Northeastern Cuba
}

\author{
Roberto Valcárcel Rojas
}

The handling of European objects by the indigenous peoples of the Antilles has been generally perceived as the naive and enthusiastic reception of an exotic and complex materiality by primitive and technologically-backward people. The picturesque image of gold exchanged for ceramic fragments, hawk bells, or pins, is recurrent. Also recalled is when the cacique Guacanagarix wore the gloves Christopher Columbus gave him, or the moment when the bravest of the indigenous chiefs in Hispaniola, Caonabo, was deceived and let Alonso de Ojeda put shining brass shackles on him. In recent years, in archaeology and anthropology, a vision has been constructed that intends to explain some of these situations by contextualizing them in systems of value to local societies. Many of the European objects were received in this way because they found room in the indigenous symbolic setting, or shared similarities with their concepts of the sacred and that imbued them with supernatural power (Keehnen 2012; Oliver 2000; Valcárcel Rojas and Martinón-Torres 2013). On the other hand, their transfer often worked as a complement to the establishment of ties of friendship and alliance, both of which indigenous peoples and Europeans were interested in promoting (Szászdi León-Borja 2015).

The barter or rescate of indigenous goods in exchange for European objects, as well as the act of gift-giving on both sides, is associated with certain objects, forms of interaction, and periods. It is in this sense that the interest of the Antillean communities in European metals such as brass can be explained. Brass resembled guanín, an indigenous alloy of gold and copper considered highly valuable since it came from very distant places - Colombia, to be precise. It was associated with mythic narratives, and with the concepts of brilliance and the numinous that marked the sacred in the perspective of diverse indigenous societies from the Antilles and South America (Oliver 2000; Saunders 1999; Valcárcel Rojas 2016a, 206-222; Valcárcel Rojas and Martinón Torres 2013). The acquisition of these objects at the beginning of the encounters and conquest was framed by processes where the indigenous peoples preserved their capacity for negotiation and choice, and in circumstances in which their traditions, symbolic conceptions, and value systems were fully functioning. 
Nonetheless, the transfer of objects through rescate and gifting was not the only way for European material culture to enter the Antillean indigenous universe. This chapter reflects on how this process was readjusted when the colonization strategy, strengthened by the experiences in Hispaniola, focused on the rest of the Greater Antilles. The expansion to these islands - which are the object of this analysis - was undertaken with a perspective that reduces the time for negotiation and contact with the indigenous inhabitants, moving quickly to take control of the population, and to the imposition of forced labor (Valcárcel Rojas 2016a, 24). In this environment, the European objects, the circumstances of their transfer, and the attitudes of the indigenous themselves at the moment of receiving them and using them, were all different. This results in diminished indigenous access to the goods used by the Europeans for gifts and rescate - part of the so-called gift kit - and the expansion of the use of other kinds of artifacts.

We assess this idea using historical and archaeological data from the Greater Antilles, primarily Hispaniola, Puerto Rico, and Cuba, as these are the most accessible. Some results of an ongoing study on archaeological material from the northeast of Cuba, developed by the author as part of the ERC-synergy project NEXUS1492, are also presented.

\section{From Gifts and Barter to the Encomienda}

The first processes of transfer or acquisition of European material culture by the indigenous peoples of the Caribbean took place in an environment of relationships where European domination had not yet been imposed. This was the so-called situation of contact (Valcárcel Rojas 2016a, 21). Specifically, the societies in contact carry with them their own experiences of socialization and interaction with strangers, as well as criteria of value originating in their respective socio-cosmic universes, which necessarily determine how the interactions occur, their content, and their feasibility ( $\mathrm{Mol} 2007$ ).

Both indigenous peoples and Europeans recognized the importance of these processes of interaction with others, and handled their own protocols previously developed in their respective cultural environments - that included the giving of goods as gifts or as a part of exchanges. This course of action should have facilitated relationships, by indicating an understanding of the importance of the counterpart, and demonstrating one's own status and the capacity to own goods. Although the true intention of the gestures was often not understood by either side, generally, the act of giving goods was reciprocated. Afterwards, the traded objects flowed through both groups' 
interaction networks in an independent and parallel manner. In the case of the indigenous communities, the European objects tended to be controlled by the elites and quickly reached their exchange networks, often preceding the arrival of the Europeans themselves (Wilson 1990, 4).

At the same time, giving and receiving originated with the purpose of obtaining goods from the other party. Thus, the value of the objects that were given and obtained was more important than the prestige and networking that the exchange may have offered the traders. This is the action of rescate itself, and it is based on the great differences of value that each side attributed to the goods in movement; each side perceived that they obtained something much more valuable than what they gave. Rescate generally takes place between societies with different levels of technological development. Often the more technologically advanced party will subordinate the other through coercive and violent acts that may include plundering and stealing (Lacueva 2012, 547).

In the Columbian perspective, following the schemes used by the Portuguese in Africa, the commercial activity related to the rescate of gold, spices, and goods of European interest, would have to have a sufficiently broad and productive scale to become a key part of the economic activity in recently discovered lands. The colonizers' primary goal was not populating these lands. Instead, they wanted to implement a commercial-military system oriented at resource extraction, including slavery and the sale of indigenous peoples. For the purpose of using them in the rescates or trade on Hispaniola, goods that had proven useful in former transactions undertaken by the Europeans in other places were imported, such as glass beads, hawk bells, and garments, among others. In practice, objects of many kinds were used, mainly those of ceramic and metal that often were damaged or were fragments of larger pieces. Columbus attempted to regulate and achieve the control of the rescates with the goal of channeling to himself and the monarchs the greater profit, and used giftgiving selectively in order to build ties and denote his position.

When the indigenous peoples of Hispaniola rejected ties to the Europeans, and it became clear that their incorporation into the commercial system Columbus intended to establish was not viable, as it was beyond their productive capacities to procure the gold expected of them, a general tribute was imposed in the wake of military subjugation of the island (Cassá 1992, 179-186). Henceforth, the Europeans moved to the appropriation of indigenous labor, a move finally formalized as the encomienda system between 1503 and 1505 (Valcárcel Rojas 2016a, 23). Under these new circumstances, rescate as a commercial option, and object exchange as a means to foster or sustain alliances and friendships, declined and disappeared. According to some 
scholars, the end of these kinds of interactions occurred around 1497 when tribute collection collapsed and the crisis of indigenous structures and their leadership and population became evident (Keehnen 2012, 128).

The encomienda implied an assignment-subordination of a group of indigenous peoples to a Spanish colonist (encomendero), so they would work for his benefit several months per year. The indigenous peoples were supposed to receive religious and civilizing education in return. According to Bartolomé de Las Casas $(1875$ c, 78$)$, in 1503 the Queen ordered that the indios from Hispaniola be paid for their work. Payment was done with objects such as beads, espejuelos (fragments of mirror), and combs, although rarely did the Spaniards really comply with the payment. The indigenous peoples called this payment the cacona.

In 1512, the Laws of Burgos - "for good treatment of the indios" - attempted to regulate this process, specifying forms of monetary compensation and giving of goods to the indios. The law specified that the indigenous peoples should be given land to start living close to the Spaniards, and that, in order to facilitate their subsistence, the encomendero should provide the community under his control with maize to sow, a dozen hens, and a rooster. The encomendero would also give a hammock to each indio and a gold peso per year to acquire clothes; the cacique was required to receive better treatment in regard to his payment and clothing (Muro 1956). Las Casas (1875c, 435) comments that with such a poor payment it was impossible to buy clothes. Diverse historical references regarding Cuba, Hispaniola, and Puerto Rico, show that during the term of labor, especially in mining and agriculture, the encomenderos supplied the indigenes with food and the necessary tools for work, although some cases are mentioned where the indigenous peoples had to use their own wooden and lithic tools and supply their own food (Sued Badillo 2001, 325).

\section{$2 \quad$ Things for Indios}

In the Antilles, the use of objects for rescate or trade with the indios as well as for gifts, was a practice derived from European commercial strategies, particularly, the ones practiced by the Portuguese in Africa. In fact, Columbus requested merchandise for the rescate when he presented his project of traveling to the Indies to the King of Portugal, as well as to the monarchs of Castile and Aragon. The required objects were: hawk bells, brass chamber pots, brass sheets, bead strings, mirrors, scissors, knives, needles, pins, linen shirts, colored coarse cloths, and colored bonnets (Las Casas 1875a, 219, 237). 
In the diary of Columbus' first voyage (1492), he registers rescates and gifts in the Bahamas, Cuba and on Bohío Island, later called Hispaniola. The interest of the indigenous peoples in everything coming from the Europeans stands out. On his second voyage, the main goals were the development of commercial activity, and the establishment of spaces where these activities could be carried out. It is for this reason that this voyage was meticulously planned, including the material resources to be used. On this occasion, the rescates were important not only to obtain gold - of which they obtained significant amounts - but also food (Álvarez Chanca 1977, 92; De Cúneo 1977, 30).

In the case of the Spanish, particularly their circum-Caribbean voyages, the rescate system functioned within the plan of discovery and to a lesser degree during the action of conquest. Nonetheless, the rescate system tended to diminish and disappear when settlement was considered, and especially, once control over local societies had been achieved. In fact, there is an entire group of voyages, undertaken between 1499 and 1502, that are denominated "Lesser voyages" or "Andalusian voyages of discovery and rescate" aimed at obtaining geographic information and discovering new lands. These were complemented by the action of bartering with the indios with the goal of producing economic dividends, but also facilitating communication and friendly relations. The rescate, especially of gold, pearls, guanín, and slaves, was regulated in regard to the areas where it could be practiced, the taxes to be paid for the benefits obtained, and the circumstances in which it was to be carried out (Alonso 2005; Gutiérres 2009). Logically, apart from the rescate, the indigenes could also have obtained diverse objects abandoned by Europeans or salvage them from shipwrecks.

The set of objects to be used in rescates and gifts, or the gift kit, according to Brain $(1975,130)$, continued to develop throughout the sixteenth century and it would be used in multiple areas of the New World into the seventeenth century. This set would mainly consist of glass beads and hawk bells, with variations that included the incorporation of artifacts in regard to regional or cultural preferences. As a system, it would become more nuanced according to the characteristics of the indigenous societies and their level of autonomy; in some cases, it would play a fundamental role in the transformation of these societies. The entry of new European powers into the discovery, conquest, and colonization processes would also give the system diverse forms, ${ }^{1}$ influencing the formation of large indigenous exchange networks, the transformation

1 The diverse expressions of trade and gifts, depending on the geographical area, historical moment, type of context and other factors, generate diverse archaeological patterns (see Dalton-Carriger 2016; McEwan and Mitchem 1984; Worth 2016). 
of the links between communities and the balance of leadership and power between these societies (Gassón 1996; Smith 1984).

In documentary terms, Hispaniola is the place in the Greater Antilles where the issues of rescate and gifting can be best studied. Information about Puerto Rico, Cuba, and Jamaica is relatively scarce, compared to Hispaniola. The data for Cuba and Jamaica principally come from Columbus' voyages (Álvarez Chanca 1977; Colón 1961; De Cúneo 1977; Las Casas 1875b, 62). Until 1508, when the conquest of these islands began, colonial actions remained focused on Hispaniola, and contact with the peoples of these outlying territories was sporadic, which meant that the rescates occurred on a limited scale.

The action of conquest in these outlying territories followed a different scheme from the one on Hispaniola, partly due to the experiences of dominion found there. By combining negotiations with military actions, a situation of Spanish predominance was attained more swiftly, while the rescate and gift giving acquired a secondary character. The main goal in these cases was not obtaining goods by means of rescate, but controlling the indigenous peoples and using them for gold extraction, or to produce resources and services that were necessary for the colonial project. The control of the workforce was reached through diverse methods, generally through the mediation of caciques. The encomienda was imposed in a relatively short time: in 1509 in Puerto Rico, in 1513 in Cuba, and in 1515 in Jamaica (Cassá 1992, 224-237; Fernández 1966; Marrero 1993, 168).

With the beginning of the encomiendas, the transfer of material culture to the indigenous peoples seems to focus on giving clothes as a payment for services. In 1506, on Hispaniola, shirts and other garments were given to the $c a-$ ciques Yaguax and Caicedo as payment for their work on constructions in the city of Santo Domingo (Mira Caballos 2000, 107). In Cuba, Gonzalo de Guzmán rewarded his indios in Bocas de Bani with 50 shirts and tools for the service they gave in the recovery of goods from a shipwreck (Real Academia de la Historia 1888:4, 233). The payment of cacona in Cuba was still mentioned in 1544 (Sarmiento 1973, 99).

A detailed record of payments to the indigenous peoples under the encomienda in Puerto Rico, between 1510 and 1519, is well known (Tanodi 1971). The cacona given to different caciques and their people, consisted mainly of garment elements: bonnets, pointed hoods, doublets, smocks, petticoats, long underwear, servillas (a thin-soled shoe), shirts, zaragüelles (knee length, open bottomed shorts), breeches, head cloths, shoes, espadrilles, and belts. Combs, mirrors and glass bead strings were also given in lesser quantities. This final group of objects was almost exclusively given to women, and in most cases, to female caciques, caciques' wives, and their captains. Their use as payment is 
recorded during the first years, and then gradually decreases. There are records of shipments of hawk bells to the island during this period, but they are not referred to as part of the cacona.

The existence of payments in the context of the encomienda does not exclude gift giving and perhaps bartering situations. Nonetheless, this seems to be rare, and the materiality used points to interests that are closer to the perspectives of appearance and life that were imposed by Europeans, and that the indigenous peoples were progressively incorporating. For example, in Cuba, Diego Velázquez bequeathed clothes to his indios in his will, and, in 1533, garments were given in Hispaniola to the rebel cacique Enriquillo and his group of renegade indios during the peace negotiations the Spaniards held with him (Fernández de Oviedo 1851, 146; Torres de Mendoza 1880, 518).

\section{The Archaeological Record}

A large part of the indigenous sites with European material identified in the Antilles are found in Cuba and Hispaniola. In the case of The Bahamas, the scarce material found (ceramic fragments, a coin, nails, glass beads, knife blades, etc.), mainly at the Long Bay and Three Dog sites, has been considered as typical of an interaction where the indigenes seem to have had some autonomy (see Berman and Gnivecki, this volume). They are explained as: (1) typical of initial rescate activity; (2) goods obtained in the context of indigenous exchange networks, which quickly incorporated exotic objects from the Spaniards; and, (3) those recovered by the indigenes from a Spanish shipwreck, or from a place where the Spaniards abandoned them (Blick 2014; Gnivecki 2011).

In Puerto Rico, according to Anderson-Córdova (2005, 350-351), and Deagan $(1988,205)$, few sites with this peculiarity have been confirmed. The sites on Mona Island are notable for the variety of artifacts that have been found (from glass beads to coins), and because they suggest diverse forms of indigenous manipulation across a long period of time (from AD 1493 to 1590) (Cooper et al. 2016; Samson and Cooper 2015). In Jamaica, there is mention of three indigenous sites with European materials, all of them close to the Spanish settlement of Sevilla la Nueva (Deagan 1988, 205). Recent studies in one of these sites, Maima, suggest forms of resistance associated with a limited use of Spanish material culture (see Henry and Woodward, this volume).

Data from Hispaniola regarding anywhere from 18 to 32 sites (see Keehnen, this volume; Valcárcel Rojas 2016b, 221) are scarce and in only a few cases come from detailed studies (Ernst and Hofman 2015; Hofman et al. 2014; Keehnen 
2012, this volume; Valcárcel Rojas et al. 2013; Vega 1987; Samson 2010). These sites can be summarized as follows:

- There was a limited presence of European objects, with fragmented ceramics and diverse metal fragments or small metal objects (sheets, rings, pins, buckles) occurring most frequently. Fragments of glass objects are reported but in most cases their chronology is unknown. Some authors mention frequent reports of glass beads (García Arévalo 1978), however, they are very rare in known sites (see Keehnen this volume). There are few references to weapons or tools (García Arévalo 1978; Ortega 2005). Keehnen (2012, 158) relates the limited presence of European objects to the quick incorporation of these artifacts into indigenous networks of interaction and exchange, producing a wide spatial dispersion. The idea of a quick incorporation and wide distribution of these items throughout the island, in virtue of the intensity of exchange processes with the indigenous population, has also been used to explain their scarcity in the Spanish settlement of La Isabela, where a great quantity of these objects was brought during Columbus' second voyage (Deagan 2002).

- There were European ceramic vessels and fragments, together with indigenous vessels, as funerary offerings in indigenous burial grounds (García Arévalo 1978); depositing of European objects (brass sheets, rings, buckles, hawk bells) together with valuable indigenous objects in protected places of potential ceremonial meaning (Ortega and Fondeur 1976; Vega 1987, 30-31); incorporation of these artifacts and materials (mirrors, jet beads, brass pins and metal sheets) into indigenous objects of great symbolic importance such as idols and cotton belts (Ostapkowicz 2013, 303; Vega 1987, 31); manufacture of ritual objects from Spanish materials (lead three-pointers) (García Arévalo 1978). These cases indicate the importance of the artifacts and European materials by virtue of their exoticism and potential link to indigenous concepts of the sacred, as well as a use focused on the elites and the ceremonial and ritual worlds.

- There were rare imitations of European ceramic vessel forms using indigenous technology and local materials.

In the case of Cuba, about 30 indigenous sites with European artifacts are known $^{2}$ (Valcárcel Rojas 2016b, 221). The four that are not in the east of the island are characterized by small quantities of artifacts, which are mostly

2 There is information on European artifacts from other indigenous sites but because of the chronology of the materials and their stratigraphic positioning their use by the indigenes is doubtful. 
ceramics (Knight 2010; Pendergast 2003; Tomé and Rives 1987). In the eastern region, the sites are mainly concentrated in the northern area, in the modern Holguín Province where 20 sites are reported. In the remaining areas of eastern Cuba, the common pattern is the presence of ceramic. Occasionally, horseshoes and fragments of diverse metal artifacts are found in small quantities (Martínez Arango 1997; Morales Patiño and Pérez de Acevedo 1945; Romero 1981).

In the following, I assess the available information from the sites in presentday Holguín Province (Rouse 1942; Valcárcel Rojas 1997) and the direct analysis from seven of these sites of European artifacts and artifacts associated with the interaction between indigenous and Europeans. This is one of the Cuban regions where the indigenous societies with Meillacoid pottery settled early on (Aguas Gordas site: MO-399, $1000 \pm 105$ BP; 2 sigma cal AD 801-1258) and reached greater demographic and cultural power. Although Spanish settlements were not founded there until the eighteenth century, there are signs of the existence of several encomiendas and the presence of indigenous descendants until the nineteenth century (Valcárcel Rojas 2016a, 67-71).

At these 20 sites, there are 43 artifacts generated by the indigenous use of European material or the imitation of European shapes or elements, 2201 European objects, and 10 non-Antillean indigenous objects. These last were potentially imported during the colonization process of the island. There are also objects that could not be quantified, so for many types of objects the quantity was greater than what was analyzed. For instance, many artifacts could often not be identified because of their deteriorated condition.

These materials come from surface finds and controlled excavations. Several are associated with middens and in one case (El Chorro de Maíta) with funerary context. Eleven of these sites have clear evidence of a settlement that was initiated prior to European arrival, although it is possible that this was also the case in the remaining sites. These are mainly habitational sites, some with occupations of several centuries and signs of settlements of large proportions and socio-political importance, in particular Potrero de El Mango and El Chorro de Maíta (Persons 2013; Valcárcel Rojas 2002).

At eight sites, the indigenous manipulation of European material is evidenced (beads manufactured from majolica fragments, modified ceramics, an indigenous axe made of iron, pendants made of metal sheets, etc.). Also, these sites have objects that were crafted to imitate European shapes or elements (imitation of vessel shapes and candlesticks) (Figure 5.1). Most of these materials are found at only two sites: El Yayal and El Chorro de Maíta. The most common are the imitated European vessel forms and the modified European ceramic fragments for diverse purposes. 


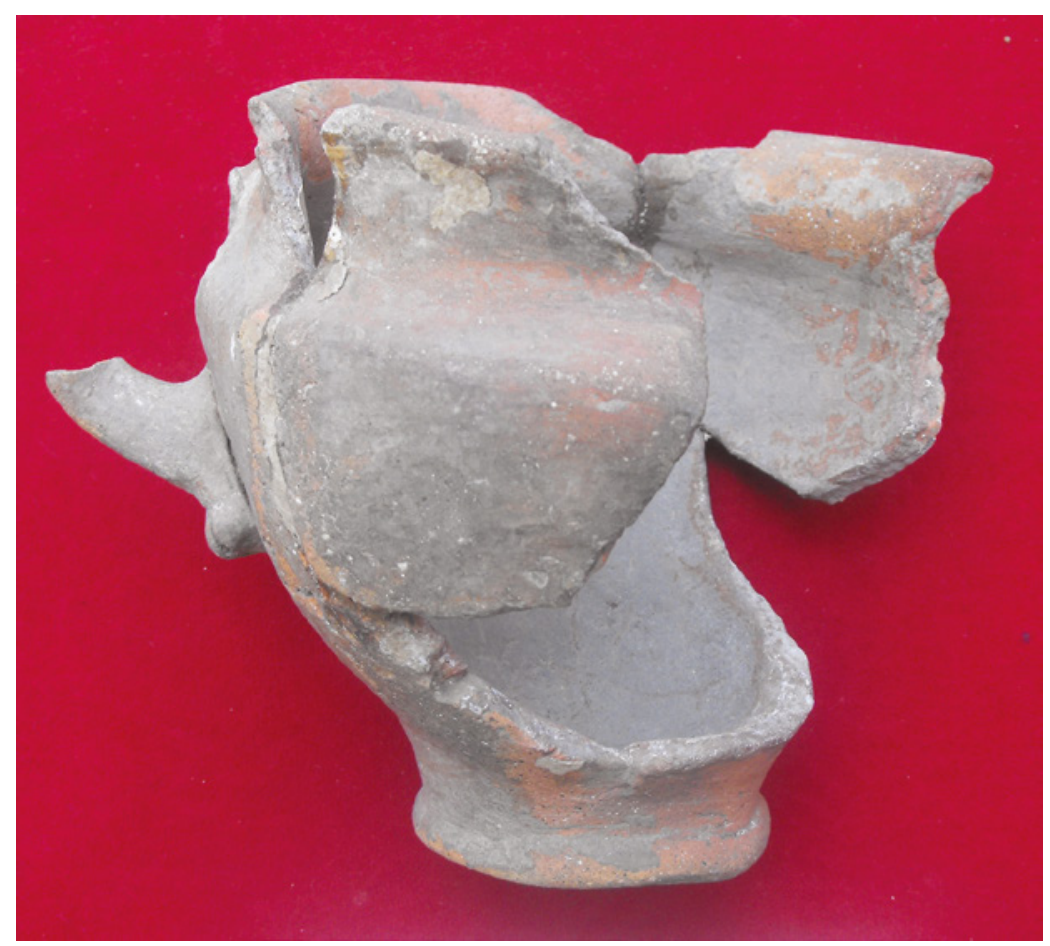

FIGURE 5.1 Indigenous vessel that copies a European form. El Yayal site, Cuba PHOTO BY ROBERTO VALCÁRCEL ROJAS

Ceramics are the most reported objects, being found at 16 of the 20 sites. Of these the early-style olive jar, Columbia Plain majolica, and melado-type lead glazed coarse earthenware stand out (Figure 5.2). Whole vessels have been identified only in a few cases, although the great volume of fragments found at some sites suggests that the indigenous peoples had access to whole vessels with some frequency. Most common are glazed ceramics.

Glass objects are infrequent. Glass beads are found at only four sites; usually one to two pieces. At the Alcalá site alone, nine pieces of Chevron and Nueva Cádiz beads, and a necklace of 103 unidentified blue glass beads were found. In El Chorro de Maíta 105 red coral beads and one jet bead were found. The latter were associated with human burials and with circumstances that suggest their use as part of the evangelization process of the indigenous population (Valcárcel Rojas 2016a, 258).

Aglets and pins are rare. They were only found at two sites, and in the case of El Chorro de Maíta, they seem to be linked to the use of clothes by the indigenous peoples (Valcárcel Rojas 2016a, 222). Equally scarce is the evidence of 


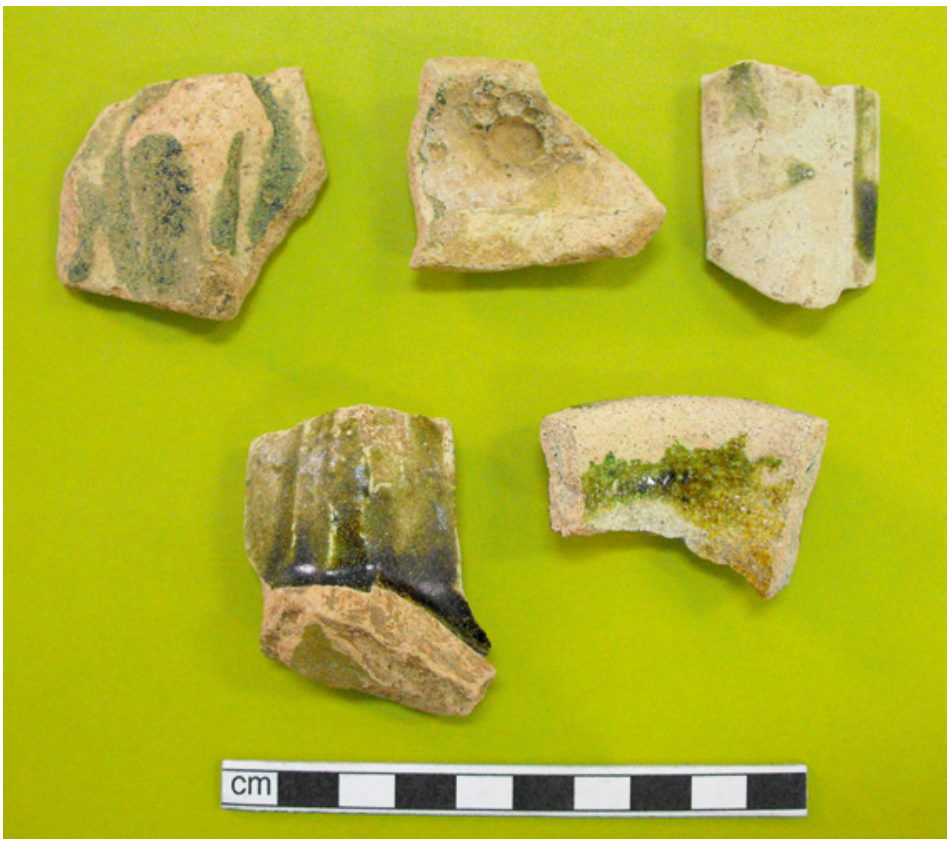

FIGURE 5.2 Glazed olive jar ceramic fragments. El Chorro de Maíta, Cuba PHOTO BY ROBERTO VALCÁRCEL ROJAS

other objects of personal use such as buckles, belt hooks, and rings. There are $5^{2}$ sheets of brass or non-ferrous metal distributed across seven sites, which indicates popularity in the use of these objects and material (Figure 5.3).

Rumbler bells (hawk bells) appear at four sites, with El Yayal having eight of the 13 recorded pieces. This site also provided six of the nine identified coins, all from the sixteenth century. In regards to architectural and furniture elements, as well as locks, El Yayal together with Alcalá and El Chorro de Maíta (the latter in lesser proportion), have most of the pieces, although they are also present at other sites. In total, there are seven locations where these objects are reported. Architectural and furniture elements are the most common metallic pieces found ( 85 objects), especially nails ( 74 of them).

Tools were found at eight sites, for a total of 38 pieces. The most common among the pieces are: knives, scissor blades, and iron chocks. Among the identified artifacts, there are hoes, axes, chisels, and pliers (Figure 5.4). There are eight sites with 38 armament-related artifacts - mainly fragments of edged weapon blades. As for horse riding gear, there are $5^{2}$ pieces distributed 


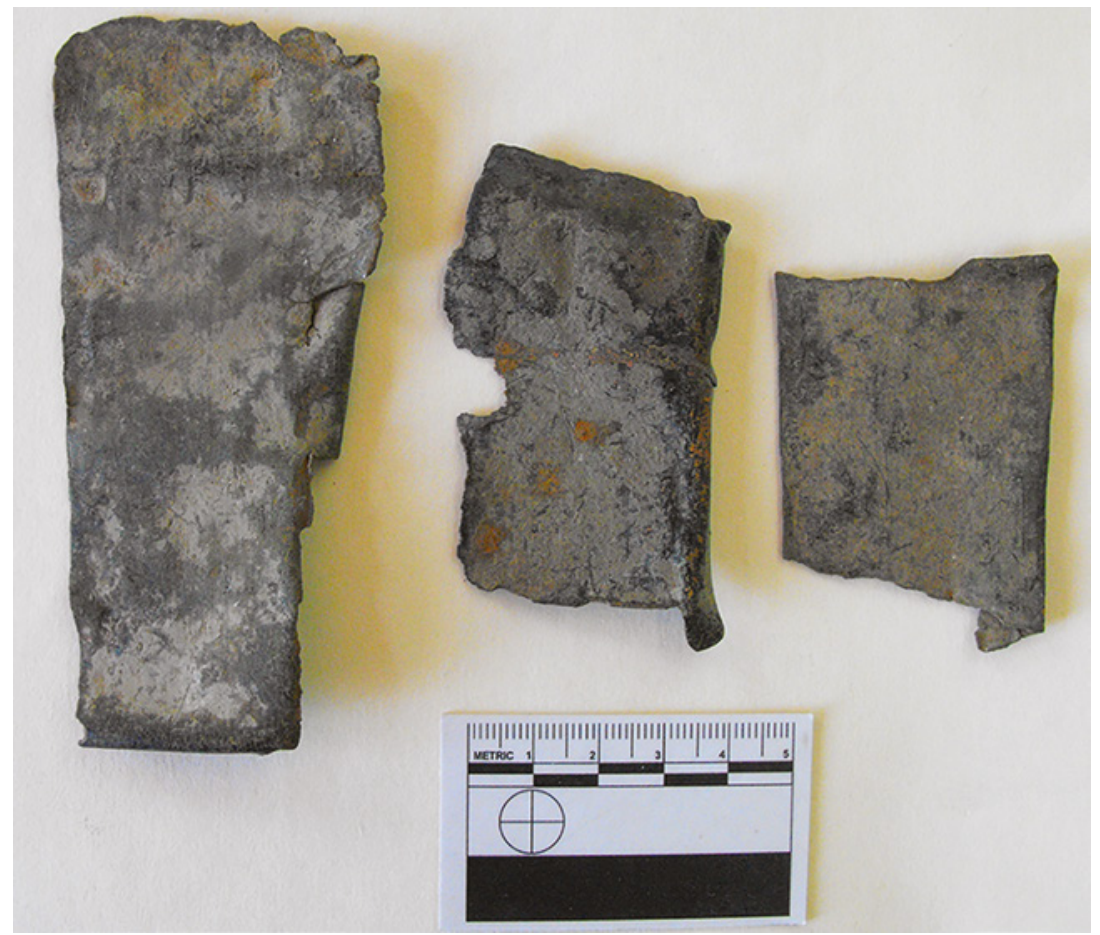

FIGURE 5.3 Sheets of non-ferrous metal, possibly brass. El Yayal site, Cuba PHOTO BY ROBERTO VALCÁRCEL ROJAS

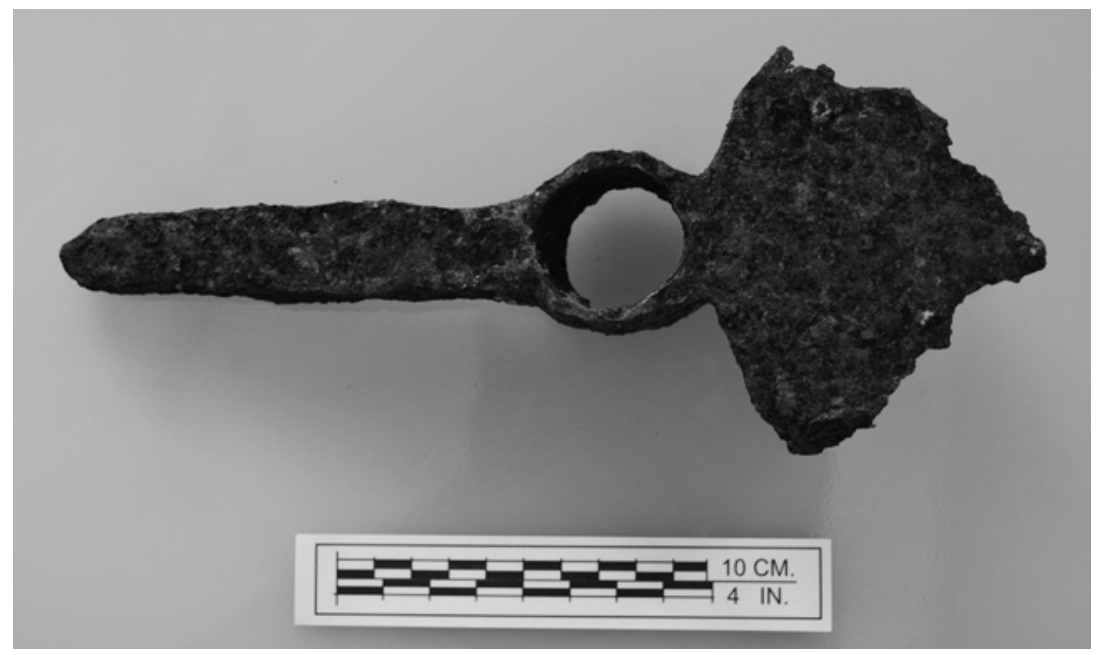

FIGURE 5.4 European tool. El Yayal site, Cuba

PHOTO BY ROBERTO VALCÁRCEL ROJAS 


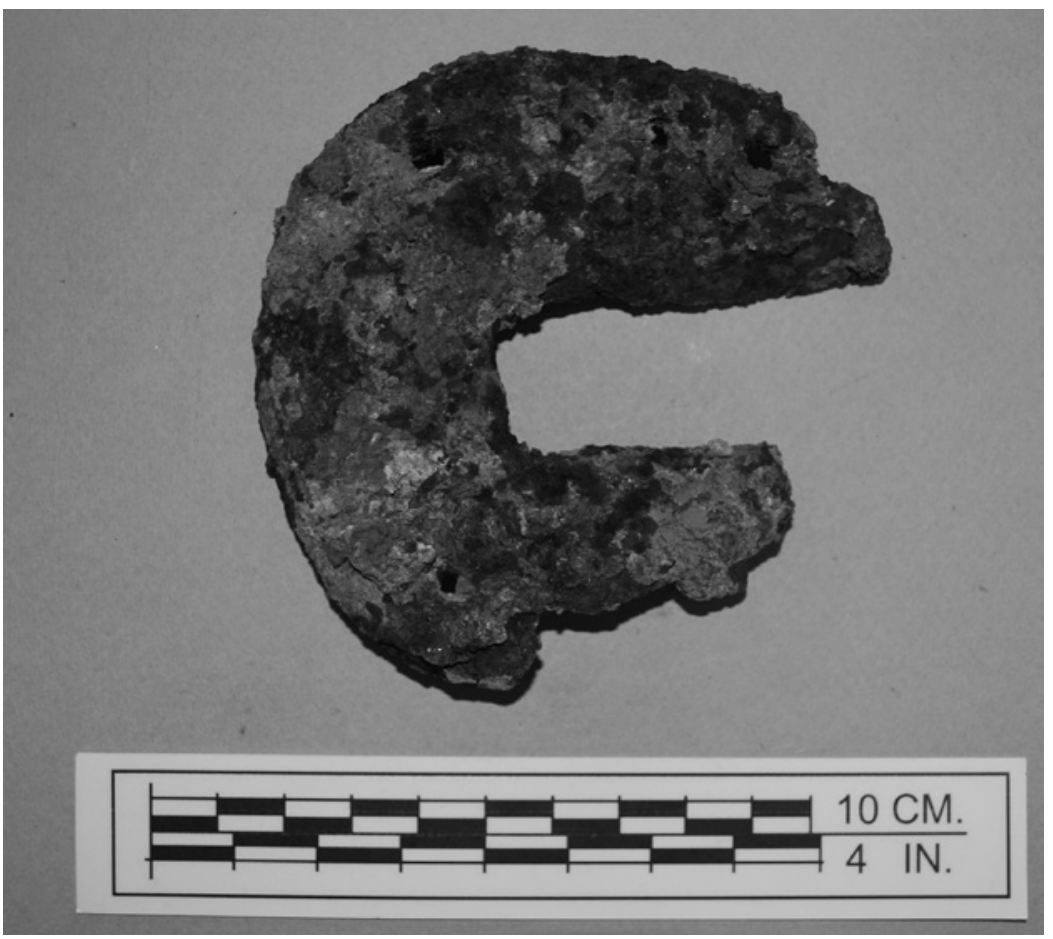

FIGURE 5.5 Horseshoe. Alcalá site, Cuba

PHOTO BY ROBERTO VALCÁRCEL ROJAS

across 6 sites, where the predominant objects are horseshoes or their fragments (Figure 5.5).

Non-Antillean indigenous evidence was found only at two sites. The evidence found in El Chorro de Maíta, which consist of guanín, Mexican Red Painted and Aztec IV ceramics, and non-Antillean indigenous pottery (the majority of all the recorded objects) seems to be linked to acts of importation promoted by the Europeans. Its use in several burials, with diverse indicators of high status, is associated with the processes of interaction with local elites promoted by the Spaniards. The presence of human remains of non-Antillean or non-local indigenous individuals, considered slaves, could also be linked with the presence of these objects (Valcárcel Rojas 2016a, 300).

The materials from these 20 sites are numerous and show great diversity. This fact suggests different schemes of use and acquisition of this materiality, potentially related to the distinct functions and chronologies of the sites; it also points to diverse modes of interaction with the Europeans, particular to the circumstances of conquest and colonization in Cuba. In any case, this is a 
panorama that is different from what is known - still very tentatively - from the other islands, especially Hispaniola.

Despite differences in the types and quantities of objects found at the studied sites in the northeastern part of Cuba, there are some general tendencies that are useful to assess processes of interaction. Except for brass sheets and non-ferrous metal, the components that are usually considered as part of the gift kit (glass beads, hawk bells, rings, and personal accessories), are limited in terms of quantity and reporting at sites. Although it cannot be dismissed that some of these and other objects relate to rescate or indigenous acquisition in circumstances of autonomy, it is likely that at some sites their presence is due to links with certain elite indigenous individuals receiving payment for services or the promotion of religious attitudes; e.g., glass bead necklaces at Alcalá and coral bead necklaces at El Chorro de Maíta. In any case, the secondary character of the action of rescate is shown as well as the probability that the presence of these artifacts indicates other functions.

Artifacts not typical of the gift kit, at least in the Antillean case, such as weapons, tools, and architectural and horse riding elements, are quite common and are found even at sites with small collections. This points to a type of interaction that was frequent and where these objects were important. It also indicates that these were objects that were used in places where Europeans and indigenous peoples interacted in a regular basis, or in indigenous villages that were under European control, rather than being used more causally for exchange or gift-giving. In their diversity, they point to a profile associated with the process of colonization that could be correlated to spaces of labor and settlement. In the rural universe, farms and mines developed material culture that could be transferred to the indigenous peoples and their villages; even in some cases, indigenous settlements were modified and refashioned as mining camps and annexes to Spanish farms. There are historical records, as the one mentioned above, regarding the payment of Gonzalo Guzmán to his indios that evidence the giving of tools to the natives.

Considering the historical and archaeological information on the encomiendas in this region, and the distribution patterns of material culture mentioned above, it is possible that many of the objects found at the sites in northeast Cuba were part of the cacona. In this sense, the evidence for clothing used among the indigenous individuals buried at the cemetery of El Chorro de Maíta is important (Valcárcel Rojas 2016a, 222).

In the cases where an assessment can be made of the way Spanish materiality was used, an attitude of sacralization or valuation of exoticism does not arise. These European-indigenous artifacts regularly appear with indigenous objects and frequently were treated as waste. In El Chorro de Maíta, where the 
population was left under an encomienda regime and a cemetery of colonial character was established, the way in which materiality and religious, funerary, and European civilizing codes were treated points to an adjustment to the norms of the colonial setting. European material culture is apparently integrated as part of the dress code along with Christian religious paraphernalia (coral beads and jet). A portion of the objects incorporated into the burials, those of non-Antillean indigenous character (such as guanín), are related to local symbolic conceptions and are particular to the elite, who incorporated Christian religiosity in a way that diversified the funerary ritual. ${ }^{3}$ This is an acquisition that belongs to a process that does not exclude old codes, but from which there emerges a new individual and a new ethno-cultural entity: the indio (Valcárcel Rojas 2016a, 323).

The sites of El Yayal, Alcalá, and El Chorro de Maíta, concentrate the largest and most diverse collections. They seem to follow a pattern where the access to European material is related to the labor functions of these populations and spaces, and to the possibility that these belong to encomienda contexts. In fact, the study of diverse lines of evidence has determined this to be true at El Chorro de Maíta (Valcárcel Rojas 2016a).

This is not necessarily the nature of the remaining sites, although the fact that they have a less important material record does not exclude the possibility that their inhabitants may have been under this type of system. As the encomienda moved the labor force out of its villages, it may have been the case that some communities, which lived under this system, incorporated limited Spanish materiality into their original life spaces. Likewise, it is possible that any of these sites may have incorporated Spanish material in circumstances prior to the establishment of the encomienda. In the case of El Yayal and Alcalá, there are historical references that suggest that they could have kept functioning as spaces with indigenous presence or that of their descendants, beyond the end of the encomiendas in 1553. This may have influenced the complexity and peculiarity of their archaeological record (Valcárcel Rojas 1997). In these circumstances, European material culture might be connected to the presence of Spaniards themselves at such sites.

The behaviors identified at the sites in Holguín Province indicate the importance of this region in the conquest and colonization processes in Cuba, as

3 The incorporation of European objects to indigenous burials, signaling the social position and reinforcing local traditions, is widely documented in other parts of the continent (Hally 2008; McEwan and Mitchem 1984). The process is modified or totally transformed, to the same extent that the control of the Europeans over the indigenous populations increases (Graham 1995, 1998; McEwan 2001); this does not exclude situations of persistence, resistance, and syncretism. 
well as the intensity of the link between Europeans and indigenous peoples. The discovery of this evidence is undoubtedly associated with the prevalence of archeological research in this area, and such evidence probably is not exclusive to this region. This outlook indicates that forms of interaction and use of European materiality that included independent ways of accessing it, and its incorporation into local cultural codes, were possible. However, these forms did not have the same relevance that can be observed in Hispaniola, and were soon substituted by others that were imposed or generated in the context of circumstances of Hispanic domination, which could have been channeled by the indigenous peoples to facilitate their existence and adaptation to the colonial context.

\section{4}

\section{Conclusions}

Available historical data, particularly from Puerto Rico, as well as archaeological information from Hispaniola and that derived from the Cuban case, support the idea that on Puerto Rico and Cuba transfer schemes of material culture to the indigenes were different from those on Hispaniola. A similar situation probably occurred on Jamaica. This is due to a colonization process that did not have the goal of obtaining goods through rescates, but rather, by extracting gold and other resources through the concentrated labor of the local population. In these circumstances, the link with the indigenous peoples originated from a position of domination, and the material culture that passed to the indigenous peoples had other characteristics and was transferred through different channels. In contrast with many parts of North and South America, in the Antilles the rescate did not develop into the consolidation of systems of interaction and the creation of new and large indigenous exchange networks, but rather, it collapsed or readjusted with the imposition of forced labor.

The act of rescate and gifting ceases or diminishes when the indigenes perform forced work and their community is disarticulated. This indicates that the gift kit loses relevance, or that its objects were given from a different perspective: mainly as payment for work or service provided. On the other hand, the indigenous perspective of the Spaniards and their material culture was marked mainly by a context of dominance. This created potentially different attitudes among the dominated groups, which sought more to take advantage of the technology and other resources of the Spanish (e.g., use of tools and weapons [reported by indigenous rebels], and consumption of pork [Sus scrofa]), or to adapt to their codes of ornamentation and appearance (e.g., use of clothing), instead of the symbolic acquisition of their goods. However, both schemes may 
have coexisted at certain times, or a circumstance may have arisen that did not totally abandon indigenous cultural conceptions, but evidences their transformation. A rejection of the Hispanic artifacts must also have been a common approach.

The archaeological pattern observed in northeast Cuba suggests that on other islands where colonization occurred with similar characteristics, there could be similar archaeological contexts. This could have also occurred in spaces of encomienda on Hispaniola, or at archaeological sites associated with periods where this system became predominant.

Considering these details, it becomes evident that, in the case of the Greater Antilles, the discovery of European materials at indigenous sites, including the case of Hispaniola, cannot always be interpreted as an expression of rescate or trade activities. Neither can the presence of brass sheets, beads, or hawk bells always be associated with the gift kit. The analysis of these archaeological contexts and artifacts requires a temporal and cultural assessment that is historically contextualized. This will not only prevent mistakes, but will allow us to appreciate the true complexity of the impact made by the Europeans in the region, and the richness of indigenous responses and attitudes.

\section{Acknowledgments}

The research leading to the results presented in this chapter is part of the ERCSynergy NEXUS1492 project and was funded by the European Research Council under the European Union's Seventh Framework Programme $\left(\mathrm{FP}_{7} / \mathrm{2007}^{-}\right.$ 2013)/ERC grant agreement no. 319209. The team of the Departamento Centro Oriental de Arqueología de Holguín provided their collaboration in the study of the Cuban material. I want to thank Jana Pesoutova and Jaime Pagán Jiménez for their support and help in accessing documentary sources from Puerto Rico, as well as Corinne Hofman and Floris Keehnen for their invitation to the symposium for which this text has been created. Valeria Corona and Konrad Antczak are thanked for translating the original Spanish text into English. In regards to the translation the help of Vernon James Knight is also appreciated.

\section{References}

Alonso, Icíar A. 2005. "Explorar, conocer: los intérpretes y otros mediadores en los viajes andaluces de descubrimiento y rescate." In Estudios sobre América: Siglo 
$X V I-X X$, edited by A. Gutiérrez Escudero and M.L. Laviana Cuetos, $55^{-528}$. Sevilla: Asociación Española de Americanistas.

Álvarez Chanca, Diego. 1977. "Carta de Diego Álvarez Chanca al ayuntamiento de Sevilla."In El segundo viaje de descubrimiento, edited by Fernando Portuondo, 57-97. La Habana: Editorial de Ciencias Sociales.

Anderson-Córdova, Karen F. 2005. "The Aftermath of Conquest. The Indians of Puerto Rico during the Early Sixteenth Century." In Ancient Borinquen. Archaeology and Ethnohistory of Native Puerto Rico, edited by Peter E. Siegel, 335-352. Tuscaloosa: The University of Alabama Press.

Blick, Jeffrey P. 2014. "El caso de San Salvador como sitio del desembarco de Colón en 1492. Principios de Arqueología histórica aplicados a las evidencias actuales." Cuba Arqueológica 7 (2): 29-49.

Brain, Jeffrey P. 1975. "Artifacts of the Adelantado." In Conference on Historic Site Archaeology Papers 8, edited by Stanley South, 129-138. Columbia: The South Carolina Institute of Archaeology and Anthropology, University of South Carolina.

Cassá, Roberto. 1992. Los indios de Las Antillas. Madrid: Editorial Mapfre.

Colón, Cristóbal. 1961. Diario de Navegación. La Habana: Comisión Nacional Cubana de la Unesco.

Cooper, Jago, Alice V.M. Samson, Miguel A. Nieves, Michael J. Lace, Josué CaamañoDones, Caroline Cartwright, Patricia N. Kambesis and Laura del Olmo Frese. 2016. "The Mona Chronicle: The Archaeology of Early Religious Encounter in the New World." Antiquity 90 (352): 1045-1071.

Dalton-Carriger, Jessica N. 2016. "New Perspectives on the Seventeenth-Century Protohistoric Period in East Tennessee: Redefining the Period through Glass Trade Bead and Ceramic Analyses." PhD diss., University of Tennessee.

Deagan, Kathleen A. 1988. "The Archaeology of the Spanish Contact Period in the Caribbean." Journal of World Prehistory 2 (2): 187-233.

Deagan, Kathleen A. 2002. "La Isabela y su papel en el paradigma inter-atlántico: la colonia española de la isla Española (1493-1550) desde la perspectiva arqueológica." Paper presented at The XV Coloquio de Historia Canario-Americana, Las Palmas de Gran Canaria.

De Cúneo, Miguel. 1977. “Carta de Miguel de Cúneo." In El segundo viaje de descubrimiento, edited by Fernando Portuondo, 19-56. La Habana: Editorial de Ciencias Sociales.

Ernst, Marlieke and Corinne L. Hofman. 2015. "Shifting values: a study of Early European trade wares in the Amerindian site of El Cabo, eastern Dominican Republic." In Global Pottery 1. Historical Archaeology and Archaeometry for Societies in Contact edited by Jaume Buxeda i Garrigós, Marisol Madrid and Javier G. Iñañez, 195-204. Oxford: British Archaeological Reports, International Series 2761. 
Fernández de Oviedo y Valdés, Gonzalo. 1851. Historia General y Natural de Las Indias, Islas y Tierra Firme de la Mar Océano Vol.1. Madrid: Imprenta de la Real Academia de la Historia.

Fernández, Eugenio. 1966. "La encomienda y la esclavitud de los indios de Puerto Rico. 1508-1550." Anuario de Estudios Americanos 23: 377-443.

García Arévalo, Manuel A. 1978. "La Arqueología indohispana en Santo Domingo." In Unidad y variedades. Ensayos en homenaje, edited by José M. Cruxent, 7-127. Caracas: Centro de Estudios Avanzados.

Gassón, Rafael A. 1996. “La evolución del intercambio a larga distancia en el nororiente de Suramérica. Bienes de intercambio y poder político en una perspectiva diacrónica." In Chieftains, Power and Trade: Regional Interaction in the Intermediate Area of the Americas, edited by Carl H. Langebaek and Felipe C. Arroyo, 133-154. Bogotá: Universidad de los Andes.

Gnivecki, Perry L. 2011. "Text and context: the Spanish contact period in the Bahama archipelago." Paper presented at the 14th Symposium on the Natural History of the Bahamas, San Salvador.

Graham, Elizabeth. 1995. "A Spirited Debate: Why Did the Maya Convert to Catholicism?" Rotunda 28 (2): 18-23.

Graham, Elizabeth. 1998. "Mission Archaeology." Annual Review of Anthropology 27: 25-62.

Gutiérres, Antonio E. 2009. "Las capitulaciones de Descubrimiento y Rescate. La Nueva Andalucía." Araucaria. Revista Iberoamericana de Filosofía, Política y Humanidades21: 257-276.

Hally, David J. 2008. King: The Social Archaeology of a Late Mississippian Town in Northwestern Georgia. Tuscaloosa: University of Alabama Press.

Hofman, Corinne L., Angus A.A. Mol, Menno L.P. Hoogland, and Roberto Valcárcel Rojas. 2014. "Stage of Encounters: Migration, Mobility, and Interaction in the Precolonial and Early Colonial Caribbean." World Archaeology 46 (4): 59o-6og.

Keehnen, Floris W.M. 2012. "Trinkets (f)or Treasure?. The role of European material culture in intercultural contacts in Hispaniola during early colonial times." Unpublished Research Master thesis, Leiden University.

Knight, Vernon J. 2010. "La Loma del Convento: Its centrality to current issues in cubanArchaeology." In Beyond the Blockade. New Currents in Cuban Archaeology, edited by Susan Kepecs, L. Antonio Curet and Gabino La Rosa Corzo, 26-46. Tuscaloosa: The University of Alabama Press.

Lacueva, Jaime J. 2012. "De Sevilla al Nuevo Mundo (1491-1521). La Real Hacienda y el negocio de los metales preciosos."Boletín de la Real Academia Sevillana de Buenas Letras: Minervae Baeticae 40: 543-578.

Las Casas, Bartolomé de. 1875a. Historia de Las Indias Vol. 1. Madrid: Imprenta de Miguel Ginesta. 
Las Casas, Bartolomé de. 1875b. Historia de Las Indias Vol. 2. Madrid: Imprenta de Miguel Ginesta.

Las Casas, Bartolomé de. 1875c. Historia de Las Indias Vol. 3. Madrid: Imprenta de Miguel Ginesta.

Martínez Arango, Felipe. 1997. Los aborígenes de la cuenca Santiago de Cuba. Miami: Ediciones Universal.

Marrero, Levi. 1993. Cuba: Economía y Sociedad. Antecedentes. Siglo XVI (la presencia europea). Vol. 1. Santo Domingo: Editorial Playor, S.A.

McEwan, Bonnie G. 2001. "The Spiritual Conquest of La Florida." American Anthropologist 103 (3): 633-644.

McEwan, Bonnie G. and Jeffrey M. Mitchem. 1984. "Indian and European acculturation in the Eastern United states as a result of trade." North American Archaeologist 6 (4): 271-285.

Mira Caballos, Esteban. 2000. Las Antillas Mayores 1492-1550. Ensayos y documentos. Madrid: Iberoamericana.

Mol, Angus A.A. 2007. "Universos socio-cósmicos en colisión: descripciones etnohistóricas de situaciones de intercambio en Las Antillas Mayores durante el período de protocontacto." El Caribe Arqueológico 10: 13-30.

Morales Patiño, Oswaldo and Roberto Pérez de Acevedo. 1945. "El Período de Transculturación Indo-hispánica.Contribuciones del Grupo Guama." La Habana 4: 5-34.

Muro Orejón, Antonio. 1956. "Ordenanzas reales sobre los indios. (Las Leyes de 151213), transcripción, estudio y notas." Anuario de Estudios Americanos 13: 417-471.

Oliver, José R. 200o. "Gold Symbolism Among Caribbean Chiefdoms: Of Feathers, $\mathrm{Ci}$ bas, and Guanín Power among Taíno Elites.” In Precolumbian Gold. Technology, Style and Iconography edited by Colin McEwan, 196-219. London: British Museum Press.

Ortega, Elpidio J. 2005. Compendio General Arqueológico de Santo Domingo 1. Santo Domingo: Academia de Ciencias de República Dominicana.

Ortega, Elpidio J. and Carmen G. Fondeur. 1976. Primer informe sobre piezas metálicas indígenas en Barrera. Santo Domingo: Centro Dominicano de Investigaciones Antropológicas.

Ostapkowicz, Joanna. 2013. “Made...With Admirable Artistry': The Context, Manufacture and History of a Taíno Belt." The Antiquaries Journal 93: 287-317.

Pendergast, David, Jorge Calvera Rosés, Juan E. Jardines Macías, Elizabeth Graham, and Odalys Brito. 2003. "Construcciones de madera en el mar. Los Buchillones, Cuba." El Caribe Arqueológico 7: 24-32.

Persons, Ashley. 2013. "Pottery, people, and place: examining the emergence of political authority in Late Ceramic Age Cuba." Unpublished PhD diss., The University of Alabama.

Real Academia de la Historia. 1888. Colección de Documentos Inéditos relativos al Descubrimiento, Conquista y Organización de las Antiguas posesiones españolas de 
Ultramar. Colección de Documentos Inéditos. Segunda serie, tomo 4, volumen 2 de la isla de Cuba. 25 vols. Madrid: Sucesores de Rivadeneyra.

Romero, Leandro. 1981. "Sobre las evidencias de contacto y transculturación en el ámbito cubano." Santiago 44: 71-108.

Rouse, Irving. 1942. Archaeology of the Maniabón Hills, Cuba. Yale University Publications in Anthropology 26. New Haven: Yale University Press.

Samson, Alice V.M. 2010. Renewing the House. Trajectories of social life in the yucayeque (community) of El Cabo, Higüey, Dominican Republic, AD 800 to 1504. Leiden: Sidestone Press.

Samson, Alice V.M. and Jago Cooper. 2015. "La historia de dos islas en un mar compartido: Investigaciones pasadas y futuras en el pasaje de La Mona." Boletín del Museo del Hombre Dominicano 46: 23-48.

Sarmiento, Domingo F. 1973. "Carta del Obispo al Emperador dando cuenta de la visita hecha á las villas é iglesias, y del estado en que se hallan. Año de 1544." In Documentos para la Historia de Cuba vol. 1, edited by Hortensia Pichardo, 96-101. La Habana: Editorial de Ciencias Sociales.

Saunders, Nicholas J. 1999. "Biographies of Brilliance: Pearls, Transformations of Matter and being, c. AD 1492." World Archaeology 31 (2): 243-257.

Smith, Marvin Thomas. 1984. "Depopulation and culture change in the early historic period Interior Southeast." Unpublished PhD diss., University of Florida.

Sued Badillo, Jalil. 2001. El Dorado Borincano. La economía de la conquista, 1510 -1550. San Juan: Ediciones Puerto.

Szászdi León-Borja, István. 2015. "Los pactos de hermandad entre los indios taínos y los conquistadores españoles." Clío 165:13-31.

Tanodi, Aurelio. 1971. Documentos de la Real Hacienda de Puerto Rico (1510-1519). Río Piedras: Centro de Investigaciones Históricas, Universidad de Puerto Rico.

Tomé, José and Alexis Rives. 1987. Carta Informativa no.83 (2da. Época). La Habana: Departamento de Arqueología. Academia de Ciencias de Cuba.

Torres de Mendoza, Luis. 1880. Colección de Documentos Inéditos relativos al Descubrimiento, Conquistay Organización de las Antiguas posesiones españolas de América y Oceanía sacados de los archivos del Reino y muy especialmente del de Indias. Serie 1 , Vol. 1. Madrid: Imprenta de Manuel G. Hernández.

Valcárcel Rojas, Roberto. 1997. "Introducción a la arqueología del contacto indohispánico en la Provincia de Holguín, Cuba." El Caribe Arqueológico 2: 64-77.

Valcárcel Rojas, Roberto. 2002. Banes Precolombino. La ocupación agricultora. Holguín: Ediciones Holguín.

Valcárcel Rojas, Roberto. 2016a. Archaeology of Early Colonial Interaction at El Chorro de Maíta, Cuba. Gainesville: University Press of Florida.

Valcárcel Rojas, Roberto. 2016b. "El mundo colonial y los indios en las Antillas Mayores. Repensando su estudio arqueológico." Boletín del Museo del Hombre Dominicano 47: $359-376$. 
Valcárcel Rojas, Roberto and Marcos Martinón-Torres. 2013. "Metals in the Indigenous Societies of the Insular Caribbean." In The Oxford Handbook of Caribbean Archaeology, edited by William F. Keegan, Corinne L. Hofman and Reniel Rodríguez Ramos, 504-522. New York: Oxford University Press.

Valcárcel Rojas, Roberto, Alice V.M. Samson and Menno L.P. Hoogland. 2013. "IndoHispanic Dynamics: From Contact to Colonial Interaction in the Greater Antilles." International Journal of Historical Archaeology 17: 18-39.

Vega, Bernardo. 1987. "Los metales y los aborígenes de La Española." In Santos, shamanes y zemíes, edited by Bernardo Vega, 31-57. Santo Domingo: Fundación Cultural Dominicana.

Wilson, Samuel M. 1990. Hispaniola. Caribbean chiefdoms in the Age of Columbus. Tuscaloosa: The University of Alabama Press.

Worth, John E. 2016. "Interpreting Spanish Artifact Assemblages in the Mid-SixteenthCentury Southeast: The View from the 1559-1561 Tristán de Luna Settlement on Pensacola Bay." Paper presented at the symposium Documenting Early European/ Native American Contacts and their Repercussions in the Southeast: A Symposium honoring Marvin T. Smith, 73rd Annual Meeting of the Southeastern Archaeological Conference, Athens, GA, October 27. Available in https://www.researchgate.net/ publication/309550137 